\title{
What does nature have to do with it? Reconsidering distinctions in international disaster response frameworks in the Danube basin
}

\author{
Shanna N. McClain ${ }^{1}$, Silvia Secchi ${ }^{2}$, Carl Bruch $^{3}$, and Jonathan W. F. Remo ${ }^{1,4}$ \\ ${ }^{1}$ Environmental Resources and Policy, Southern Illinois University, Carbondale, USA \\ ${ }^{2}$ Department of Geographical and Sustainability Sciences, University of Iowa, Iowa City, USA \\ ${ }^{3}$ Environmental Law Institute, Washington, DC, USA \\ ${ }^{4}$ Department of Geography and Environmental Resources, Southern Illinois University, Carbondale, USA \\ Correspondence to: Shanna N. McClain (shannamcclain@siu.edu)
}

Received: 28 September 2016 - Discussion started: 14 October 2016

Revised: 28 October 2017 - Accepted: 2 November 2017 - Published: 5 December 2017

\begin{abstract}
This article examines the international policy and institutional frameworks for response to natural and manmade disasters occurring in the Danube basin and the Tisza sub-basin, two transnational basins. Monitoring and response to these types of incidents have historically been managed separately. We discuss whether the policy distinctions in response to natural and man-made disasters remain functional given recent international trends toward holistic response to both kinds of disasters. We suggest that these distinctions are counterproductive, outdated, and ultimately flawed, illustrate some of the specific gaps in the Danube and the Tisza, and conclude by proposing an integrated framework for disaster response in the Danube basin and Tisza sub-basin.
\end{abstract}

\section{Introduction}

The actors engaged in disaster response ${ }^{1}$ have historically been determined by the nature of the disaster (i.e., natural disaster, industrial accidents, nuclear accidents, marine oil spills), and legal frameworks typically divide response be-

\footnotetext{
${ }^{1}$ While disaster response is considered part of the disaster management cycle, disaster management includes the application of policies and actions regarding disaster risk (i.e., prevention, preparedness and mitigation, response, and recovery). Each have their own set of policy frameworks, actors, and mechanisms for implementation. This paper focuses on the disaster response phase specifically, on the policy frameworks and actors related to requesting and receiving assistance immediately following a disaster, and the legal mechanisms by which responders are deployed.
}

tween natural and man-made disasters. However, there is growing recognition that anthropogenic climate change and other human activities such as land use change are driving more extreme and sometimes cascading events (Sun, 2016). Cascading events refer to cases in which a primary threat is followed by a sequence of secondary or additional hazards that require complex and often overlapping types of response (Pescaroli and Alexander, 2015). We conjecture that the tight coupling of human and environmental systems and the intensive nature of natural resource extraction and management, industrial activity and agriculture have increased the risk of cascading events. Thus, the question of eliminating the natural-man-made dichotomy in disaster response policy is brought to the forefront. We focus on transboundary response frameworks because they present exceptional logistical and technical challenges, particularly in watersheds such as the Danube and the Tisza, where countries have very disparate histories and levels of economic development and are governed by different statutes.

In Europe, natural and man-made disasters combined caused total losses of USD 13 billion in 2015, of which only USD 6 billion were insured; the predominant losses came from flood events (Swiss Re, 2016). Flooding and pollution are considered to be the primary transboundary pressures of the Danube River basin; however, a number of other man-made accidents occurred in the region (ICPDR, 2015a). Specifically, in 2000, the Baia Mare and Baia Borsa minetailing pond failures mobilized approximately $100000 \mathrm{~m}^{3}$ of metal-contaminated water into the Tisza River, eventually polluting the Danube River and Black Sea. Since the 
industrial accidents occurred originally as a result of significant rainfall and flooding, these events are an example of what are commonly referred to as "natech" accidents technological accidents triggered by natural disasters - and which lack regulation to analyze, prepare for, or mitigate (Krausmann et al., 2017). In 2010, an industrial accident occurred in the Hungarian portion of the Danube River when a dam containing alkaline red sludge collapsed, releasing 1.5 million $\mathrm{m}^{3}$ of sludge into the surrounding land (approximately 4000 ha) and waterways (including Kolontár, Torna Creek, and the Danube River), killing 10 people and injuring several hundred more (ICPDR, 2010). In 2014, following Cyclone Tamara, over 1000 landslide events occurred in Serbia as well as significant flooding, resulting in damage to properties and infrastructure and the inundation of agricultural land. Due to concern over possible breaches to mine-tailing dams in the surrounding area, and the harmful effects on human health, technical experts investigated mining sites and provided recommendations for local evacuations (NERC, 2014). In all three disasters, the need for disaster response exceeded the capacity of national actors; therefore, international response involved the United Nations, the European Commission, and various other international organizations. Thus, adequate international disaster response frameworks have already been put to task in the Danube and the Tisza. Though international humanitarian law is generally well defined, the law of international disaster response is still incomplete (Fisher, 2008). Historically, a distinction has been drawn between the scope of response to natural disasters and man-made disasters; however, this distinction is absent from the 2015 Sendai Framework for Disaster Risk Reduction, which adopts a multi-hazard risk approach providing management tools for disasters that are both natural and man-made (UNISDR, 2015). The Sendai Framework places unprecedented emphasis on the interaction between hazards (natural and man-made), exposure levels, and pre-existing vulnerability (Aitsi-Selmi and Murray, 2016). It calls for improving decision making through a stronger science-policypractice interface, with four priority areas for action - including strengthening disaster governance with regard to shared resources and at the basin level (UNISDR, 2015). The European Union's (EU) disaster response framework is also holistic and includes natural and man-made disasters, and some multilateral sub-regional agreements are also taking similar approaches, such as those adopted by the Association of South East Asian Nations (ASEAN) and the Baltic Sea Economic Cooperation (BSEC) (ASEAN, 2010; BSEC, 1998). Adopting a multi-hazard, or all-hazard, approach to disaster response allows for recognition of known conditions, natural or man-made, that have the potential to cause injury, illness, or death; damage to or loss of infrastructure and property; or social, economic, and environmental functional degradation (Kappes et al., 2012).

With international policies starting to shift toward more holistic frameworks of response that incorporate both natural and man-made disasters, this article explores policy frameworks for response in the Danube basin and Tisza sub-basin, which continue to distinguish between types of disasters and resultantly have separate response options depending on the type of disaster, and what the holistic frameworks trend could mean for regional institutions in the study basins.

This article begins with an overview of the study area and a description of the methodology. Next is a discussion of the historical distinctions in response between natural disasters and industrial accidents - how and why they have been treated differently and how recent developments in international law and practice are raising questions about the merits of these distinctions. It is followed by an examination of the international frameworks governing disaster response in the Danube basin and Tisza sub-basin, and an analysis of the monitoring and response to natural disasters and industrial accidents in the basins. The article concludes with a reflection of how the transition of international policies toward more holistic frameworks for response might affect the Danube basin and Tisza sub-basin.

\section{Overview of study area}

The Danube River basin covers more than $800000 \mathrm{~km}^{2}-$ over $10 \%$ of continental Europe - and flows through the territories of 19 countries, with nearly 80 million people residing within the basin. Today, 14 of the 19 countries, plus the EU, have committed to transboundary cooperation in protecting the Danube via the Danube River Protection Convention (DRPC) and work jointly toward the sustainable management of the Danube basin and the implementation of both the EU's Water Framework Directive (WFD) and Floods Directive (FD) (ICPDR, 2015a).

Among the tributaries of the Danube River, the Tisza subbasin has the largest catchment area and covers approximately $160000 \mathrm{~km}^{2}$ (20\% of the Danube basin's area), with approximately 14 million people (Fig. 1). There exists a distinct socioeconomic contrast in the basin between western and former socialist countries; however, since the end of communism in the late 1980s, the central and lower Danube has experienced a rapid shift to free market democracy within the context of increased globalization, privatization, and deregulation. This has been accompanied by changes in governments and institutions, affecting the continuity of policies and international arrangements which could potentially impact the international frameworks countries adhere to.

International measures regulating the Danube were first undertaken in 1882 for flood protection and navigation. Dams were constructed within the upper basin for flood mitigation, hydroelectric power generation, and regulation of river levels for navigation. The operation of these dams has been associated with altering the flow regime of this segment of river and consequently varying the ecological disturbance regime within the river and on the floodplain, 


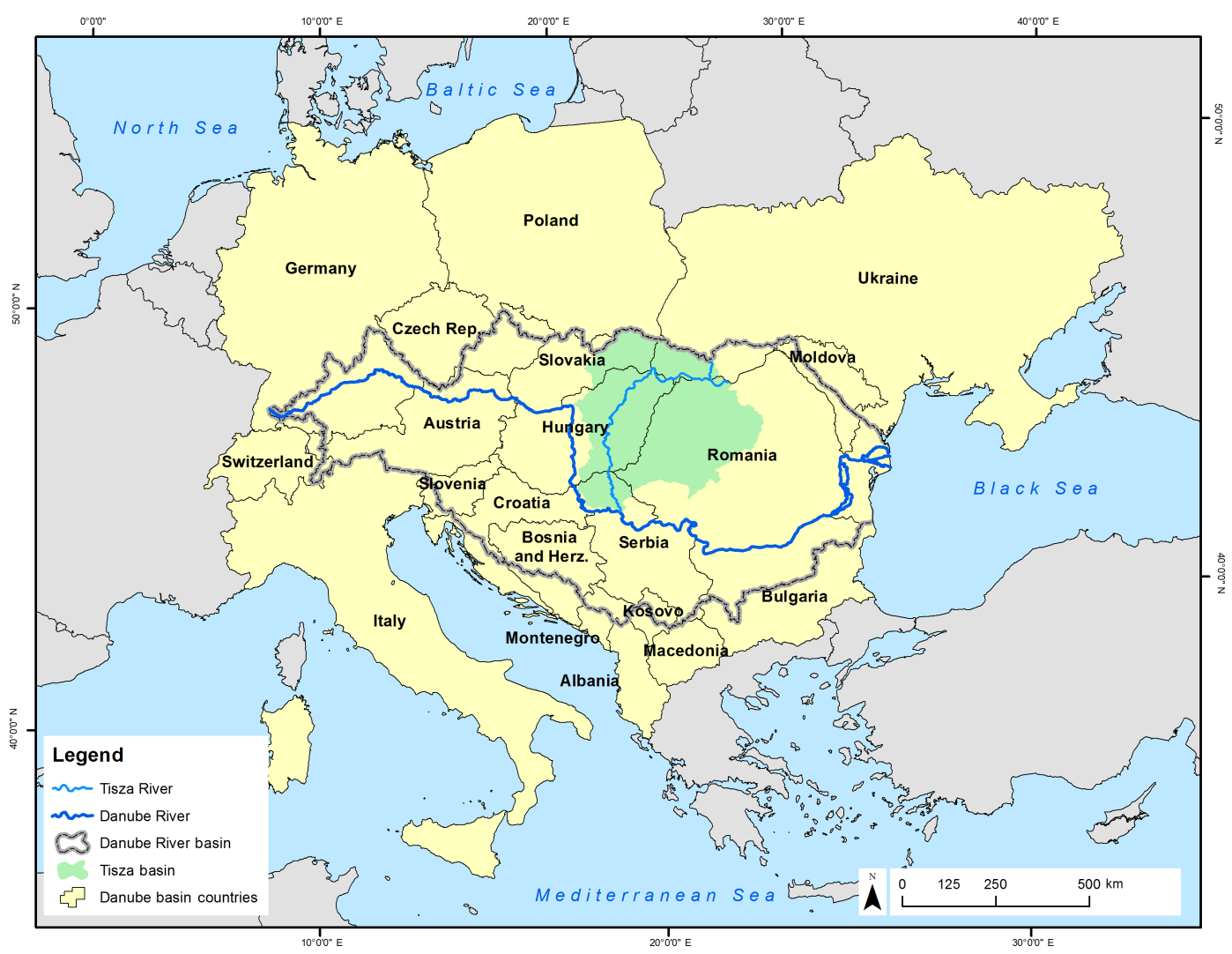

Figure 1. Map of Danube River basin and Tisza River sub-basin. Source: authors, using data from EUROSATA (2014), ICPDR (2013), and Lehner et al. (2008).

resulting in substantial changes in the riverine ecosystem (ICPDR, 2009a). The flow regulation provided by the dams and the construction of levees has allowed for the conversion of floodplains and riverine wetlands into areas suitable for agricultural and urban development. Today, only 12 small reaches ( $<1 \mathrm{~km}$ in length) of the Upper Danube remain relatively untransformed (Schneider, 2010, p. 197). In the Middle and Lower Danube, the riverbed has been dredged repeatedly to maintain a navigable river channel. Along these segments of the Danube River, levees and dams mitigate or prevent inundation of over $72 \%$ of the floodplain. The substantial reduction in Danube's connection with its floodplain combined with wastewater discharge from agricultural and industrial sources, as well as increasing levels of pollutants along these river segments, have substantially altered or damaged the riverine ecosystem and reduced the resilience of urban and rural communities to large floods, which exceed the protection level of their flood mitigation measures (Schneider, 2010; UNECE, 2011). The degree of industrial development and amount of pollution created by the industrial sector varies among Danube countries. In general, pulp and paper industries represent the largest contributors of pollution, followed by chemical, textile, and food industries (ICPDR, 2009a).
The Tisza headwaters are located in the Carpathian Mountains in Ukraine. From these headwaters the Tisza River flows southwest across central portions of the great Hungarian Plain into the Danube River in Serbia (Fig. 1; ICPDR, 2008). Intense, concentrated rainfall and the steep terrain coupled with deforestation and channelization of many streams result in some of the most sudden and highenergy flooding in Europe (Nagy et al., 2010). Sudden water level rises, coupled with the high energy of the flows, often threaten human lives and result in substantial damage to infrastructure and croplands (ICPDR, 2008).

While industrial production has dropped drastically in the Tisza region since the 1990s, a variety of industries remain, and the legacy of heavily concentrated industrial activities continues to threaten the surrounding ecosystems. The main industrial regions of the Tisza sub-basin are located in Romania and Hungary, where the potential for flood damage and losses is also greatest. Chemical and petrochemical industries (including oil refinery, storage, and transport) are important for both Hungary and Ukraine, and the cellulose and paper, textile, and furniture industries are also present predominantly in the upper portion of the Tisza in Slovakia, Romania, and Ukraine (ICPDR, 2011). 
Table 1. List of legally binding mechanisms for the Danube basin and Tisza sub-basin.

\begin{tabular}{|c|c|c|c|}
\hline Governing body & Convention & Type of instrument & Description of instrument \\
\hline $\begin{array}{l}\text { UN Economic } \\
\text { Commission for } \\
\text { Europe }\end{array}$ & $\begin{array}{l}\text { Industrial } \\
\text { Accidents } \\
\text { Convention }\end{array}$ & $\begin{array}{l}\text { Legally binding for } \\
\text { parties to convention }\end{array}$ & $\begin{array}{l}\text { Determines actions of } \\
\text { request for assistance and } \\
\text { response for industrial } \\
\text { accidents specifically }\end{array}$ \\
\hline $\begin{array}{l}\text { European } \\
\text { Commission }\end{array}$ & $\begin{array}{l}\text { Water } \\
\text { Framework } \\
\text { Directive }\end{array}$ & $\begin{array}{l}\text { Legally binding for EU } \\
\text { member states and } \\
\text { through Danube } \\
\text { Convention for non- } \\
\text { EU member states }\end{array}$ & $\begin{array}{l}\text { Sets basin-level } \\
\text { management of water } \\
\text { quality and quantity }\end{array}$ \\
\hline $\begin{array}{l}\text { European } \\
\text { Commission }\end{array}$ & $\begin{array}{l}\text { Floods } \\
\text { Directive }\end{array}$ & $\begin{array}{l}\text { Legally binding for EU } \\
\text { member states and } \\
\text { through Danube } \\
\text { Convention for non- } \\
\text { EU member states }\end{array}$ & $\begin{array}{l}\text { Requires action regarding } \\
\text { flood mapping at the basin } \\
\text { level }\end{array}$ \\
\hline $\begin{array}{l}\text { European } \\
\text { Commission }\end{array}$ & $\begin{array}{l}\text { Seveso } \\
\text { Directive }\end{array}$ & $\begin{array}{l}\text { Legally binding for EU } \\
\text { member states }\end{array}$ & $\begin{array}{l}\text { Requires corporations to } \\
\text { list possible risk of } \\
\text { industrial accident and } \\
\text { develop preparedness plans }\end{array}$ \\
\hline $\begin{array}{l}\text { European } \\
\text { Commission }\end{array}$ & $\begin{array}{l}\text { Civil } \\
\text { Protection } \\
\text { Mechanism } \\
\text { Directive }\end{array}$ & $\begin{array}{l}\text { Legally binding for EU } \\
\text { member states }\end{array}$ & $\begin{array}{l}\text { First EU-wide law to } \\
\text { include multiple-hazards in } \\
\text { disaster risk strategies }\end{array}$ \\
\hline $\begin{array}{l}\text { International } \\
\text { Commission for the } \\
\text { Protection of the } \\
\text { Danube River } \\
\text { (ICPDR) }\end{array}$ & $\begin{array}{l}\text { Danube River } \\
\text { Protection } \\
\text { Convention }\end{array}$ & $\begin{array}{l}\text { Legally binding for } \\
\text { Danube member states }\end{array}$ & $\begin{array}{l}\text { Provides integrated } \\
\text { framework for all Danube } \\
\text { countries to participate in } \\
\text { basin-level management } \\
\text { regardless of EU affiliation }\end{array}$ \\
\hline
\end{tabular}

Mining activities, and the accidental spills of chemical substances, have affected the aquatic environment and water quality within the Tisza sub-basin, as exemplified by the 2000 Baia Mare and Baia Borsa natech accidents (JEU, 2000). Natech accidents, more broadly termed environmental emergencies, present significant challenges, as natural events can trigger multiple and simultaneous accidents in one installation or, depending on the impact of the natural hazard, in several hazardous facilities at the same time (Krausmann and Baranzini, 2012; UNEP, 2011). A 2009 assessment identified more than 92 potential sources for industrial and waste deposits; however, the list does not include abandoned mine sites and their mine-tailing dams - only those from currently operational mines (ICPDR, 2015a). Therefore, the potential risk of accidental pollution could be substantially higher (ICPDR, 2015a). Furthermore, natech accidents present additional difficulties as they remain absent from disaster response frameworks (Krausmann et al., 2017).

\section{Methodology}

The policy and institutional frameworks for monitoring of and responding to natural and man-made disasters in the Danube and Tisza were examined with a combination of primary and secondary data collection and analysis. The primary data consisted of semi-structured interviews, while the secondary data included analysis of the legally binding mechanisms, conventions, and directives in the region ( $\mathrm{Ta}-$ ble 1). A review of bilateral agreements (Table 2) and of peer-reviewed publications and white papers on the provision of disaster response within the Danube basin and Tisza sub-basin highlighted the international laws, policies, and institutions present in the region. Semi-structured interviews were conducted over an 8-month period from January to August 2013. This format of interviews was chosen so that the pre-determined set of interview questions could be expanded through the natural course of conversation and allow for a more thorough understanding of what was initially queried in particular, each expert interviewed was provided with the freedom to express their personal views in their own terms. 
Table 2. List of bilateral agreements within countries in the Danube basin and Tisza sub-basin.

\begin{tabular}{lll}
\hline Countries & $\begin{array}{l}\text { Transboundary } \\
\text { watercourses }\end{array}$ & $\begin{array}{l}\text { Disasters/ } \\
\text { emergencies }\end{array}$ \\
\hline $\begin{array}{ll}\text { Serbia and Montenegro-Hungary } \\
\text { Serbia and Montenegro-Romania }\end{array}$ & $1955^{\mathrm{b}}$ & $1955^{\mathrm{a}}$ \\
Austria-Hungary & $1955^{\mathrm{b}}$ & $\begin{array}{l}\text { Under discussion } \\
1959 \text { (floods only) }\end{array}$ \\
Austria-Slovenia & 1956 & $1956^{\mathrm{a}}$ (floods only) \\
Hungary-Slovakia & $1956^{\mathrm{c}}$ & 2014 (floods only) \\
Austria-Czech Republic & $1956^{\mathrm{a}}$ & 1994 (floods only) \\
Austria-Slovakia & $1967^{\mathrm{a}}$ & 1994 (floods only) \\
Croatia-Slovenia & $1967^{\mathrm{a}}$ & $1977^{\mathrm{c}}$ (coastal pollution) \\
Hungary-Romania & No date & 2003 (floods only) \\
Croatia-Hungary & 1986 & 1994 (floods only) \\
Hungary-Slovenia & 1994 & 1994 (floods only) \\
Moldova-Ukraine & 1994 & - \\
Ukraine-Slovakia & 1994 & 2000 (floods only) \\
Ukraine-Romania & 1995 & $1952^{\mathrm{c}}$ (floods only) \\
Hungary-Ukraine & 1997 & 1998 (floods only) \\
Czech Republic-Slovakia & 1997 & - \\
Bulgaria-Romania & 1999 & 2004 (floods only) \\
Moldova-Romania & 2004 & 2010 (floods only) \\
Bosnia and Herzegovina-Serbia and Montenegrob & - & 2011 (flood emergency warning systems) \\
Bulgaria-Serbia & Draft & Draft (floods only) \\
Croatia-Serbia & - & - \\
\hline Agrata & & \\
\hline
\end{tabular}

${ }^{a}$ Agreement formed with Czechoslovak Socialist Republic. ${ }^{b}$ Agreement formed with Yugoslavia. ${ }^{c}$ Agreement formed with Union of Soviet Socialist Republics. - No information available.

Seventy-one interviews were conducted in various locations throughout Europe. The interviews took place with experts in the International Commission for the Protection of the Danube River (ICPDR), the expert groups of the International Commission for the Protection of the Danube River (i.e., Tisza group, river basin management, flood protection, and accident prevention and control), with respondents working at the national ministries, water management directorates, and non-governmental organizations in the Tisza and Danube countries as well as with experts in the European Commission and the United Nations. Those interviewed were chosen based on their knowledge of and work within the Danube River basin and Tisza sub-basin. Specifically, all individuals interviewed held positions (as reflected in Table 3) within the countries of the Danube basin and Tisza subbasin and were contacted through the ICPDR expert groups and through a snowball method whereby one person interviewed would suggest additional people to interview. Given public roles, the interviews are intentionally left anonymous to ensure candidness in the responses. Thus, only the type of organization the experts work for is identified - the numbers appearing in brackets in the table below refer to the interview citations in text; multiple interviews were conducted within each level of governance indicated (Table 3). The classification distinguishes between international (global) organization experts, professionals working in institutions within the Danube basin (regional), and experts working at national agencies and ministries. The questions focused on how international frameworks affected Danube basin and Tisza subbasin policies and laws, and how these were implemented in practice. The interviews also elicited the opinion of the experts regarding the adequacy of existing international frameworks and their impacts on policy implementation of disaster monitoring and response throughout the Danube basin and Tisza sub-basin. ${ }^{2}$

\section{Distinctions between natural and man-made disasters in policy frameworks}

The approaches used for describing, limiting, and classifying disasters fundamentally shape the methods for responding to disasters. They determine the solutions utilized, the resources allocated, and the governance frameworks selected by cate-

\footnotetext{
${ }^{2}$ Questions relevant to international frameworks for disaster response included the following: (1) what are the respective roles in multilevel governance in regard to response for natural and manmade disasters? (2) To what extent are natural and man-made disasters included in policy frameworks for response - in what context and at what level, and what is the language being used? (3) What gaps exist between policies and practice in regard to response for natural and man-made disasters? (4) What constraints or opportunities exist in including policies for response to natural and man-made disasters, and which type would be most effective and at what level?
} 
Table 3. Organizations from which experts were drawn for interviews. Numbers in brackets refer to interview citations in text.

\begin{tabular}{ll}
\hline International & $\begin{array}{l}\text { United Nations, United Nations Economic Commission for } \\
\text { Europe, and United Nations Environment Programme } \\
\text { (UNEP)/UN Office for the Coordination of Humanitarian } \\
\text { Affairs (OCHA) Joint Environment Unit [1] }\end{array}$ \\
\hline Regional & $\begin{array}{l}\text { European Commission [2] } \\
\text { International Commission for the Protection of the Danube } \\
\text { River (ICPDR) and Expert Groups (Tisza Group, River Basin } \\
\text { Management, Flood Protection, and Accident Prevention and } \\
\text { Control) [3] }\end{array}$ \\
\hline National & $\begin{array}{l}\text { National ministries of environment, rural development, } \\
\text { and interior as well as environment agencies [4] } \\
\text { Water directorates [5] }\end{array}$ \\
\hline Non-state actors & NGOs [6] \\
\hline
\end{tabular}

gorizing the types of disaster into either natural or man-made. It is therefore important to recognize the etiology of disaster to understand why the distinctions among the various types of disasters still remain.

Natural hazards are naturally occurring physical phenomena, which can include earthquakes, landslides, tsunamis, volcanoes, and floods, with a potential to create losses or dangers to humans (Smith, 2013). If the potential is realized, disasters occur. These disrupt the functioning of societies due to exposure, vulnerability, and risk - leading to human, material, economic, and environmental losses and impacts. ${ }^{3}$ Natural disasters have historically been characterized either (1) as a direct form of punishment from God for the sins of humanity or (2) more recently as an "act of God" that removed humans from culpability (Rozario, 2007). However, such a dichotomous view masks the fact that natural disasters are a function of where people reside and their overall vulnerability, including aging infrastructure, and their consequences depend on people's ability to monitor and prepare for these events (Peel and Fisher, 2016).

Industrial and other man-made disasters are traditionally governed and responded to separately from natural disasters. The fragmented nature of disaster response is a historical artifact, resulting from the need to address specific types of disasters, in specific regions, or response modalities. More recently, evidence of increased losses due to disasters (Barredo, 2009; Cutter and Emrich, 2005), legal barriers to disaster response (Janssen et al., 2010; Venturini, 2012), and the absence of unified response have led to increased

\footnotetext{
${ }^{3}$ Exposure is understood as people, infrastructure and housing, production capacities, and other human assets located in hazardprone areas. Vulnerability is defined as a set of physical, social, economic, and environmental factors or processes that increase the susceptibility of an individual, a community, assets, or systems to the impacts of hazards. Disaster risk is the potential loss of life, injury, or damaged assets occurring to an individual or community as a function of hazard, exposure, and vulnerability (UNISDR, 2015).
}

attention at a variety of levels for more integrated international frameworks (IFRC, 2007). However, currently, natural disasters and industrial and nuclear accidents have established frameworks for response, while natech accidents are often missing from response programs (OECD, 2015). Natech accidents can lead to the release of toxic substances, fires, or explosions and result in injuries and fatalities; therefore, the lack of consideration for natech response mechanisms, planning tools, or response programs can be an external risk source for chemical and nuclear facilities (Krausmann and Baranzini, 2012). Nuclear accidents are an exception, as they are holistically covered by the Convention on Assistance in the Case of a Nuclear Accident or Radiological Emergency and the Convention on Early Notification of a Nuclear Accident, which were adopted almost immediately following the Chernobyl nuclear accident. However, there still remains no similar overarching global framework for notification or assistance in response to industrial accidents or for natech accidents more broadly (Bruch et al., 2016). Other disaster frameworks, like the Tampere Convention, apply only to a single sector or area of relief. Conversely, the ability to provide disaster response for natural disasters is quite broad and is included in a number of international frameworks. A question of applicability of agreements arises, however, when a cascading disaster or a natech occurs and multiple institutions have a mandate for response, but it is unclear which institution should take the lead in responding or coordinating response efforts (Bruch et al., 2016).

\section{Disaster frameworks in the Danube basin and Tisza sub-basin and their treatment of disasters}

The Danube and the Tisza have experienced numerous natural and man-made disasters, including natech accidents (e.g., Baia Mare cyanide spill, Hungarian chemical accident, and recent Serbian landslides) (European Commission, 2016). 
There have been over 40 reported disasters in the Danube basin between 2000 and 2012, ranging from natechs to earthquakes and industrial fires. A majority of them involved more than one country at the same time (European Commission, 2016). However, the frameworks for disaster response at the levels of the United Nations, the EU, and those utilized by the ICPDR are restricted to particular types of disaster - response to flooding is the most advanced throughout the basin, while pollution is monitored but does not have the same frameworks for response. Additionally, there remain a variety of natural and man-made disasters that are not integrated into any type of basin monitoring or response framework, including fire and drought.

Response to these disasters is governed by a range of global, regional, and national laws, policies, and soft law instruments, that is, "normative provisions contained in nonbinding texts" (Shelton, 2000, p. 292). In the Danube basin and Tisza sub-basin, this includes the Industrial Accidents Convention and the Seveso Directive, the WFD, and the FD, as well as treaties and policies developed at the level of the Danube and Tisza. As such, natural and man-made disasters continue to be treated as distinct and separate issues, their monitoring and response are managed independently, and consideration for natech accidents is missing from policy guidance. Here, we discuss some of the issues that have arisen from the international/global and regional (EU and basin-wide) frameworks for response to natural disasters in the Danube and the Tisza. We consider frameworks in decreasing geographical scope.

At the international level, since there are agencies experienced in particular types of international disasters which are often without a mandate or capacity for response, the approaches used fall under the soft law umbrella. For the Danube and the Tisza, in 1994 the United Nations Environment Programme (UNEP) and the UN Department of $\mathrm{Hu}-$ manitarian Affairs (the predecessor of OCHA) developed an administrative arrangement through an exchange of letters (Bruch et al., 2016). The resulting Joint UNEP/OCHA Environment Unit (JEU) plays a leading role in facilitating coordination among international organizations in the event of natural and man-made disasters, including natech accidents. The JEU has a number of existing agreements and interface procedures in place with these organizations in order to facilitate response. For example, the JEU facilitated international agreements and interface procedures to aid with response between UN Disaster Assessment and Coordination (UNDAC) and the EU Civil Protection Mechanism (CPM) to the 2014 Serbian landslides following $\mathrm{Cy}$ clone Tamara (NERC, 2014). During the 2000 Baia Mare natech accident in the Tisza River sub-basin, 16 experts from seven countries deployed for response to the natech accident. The JEU assisted to coordinate response efforts among UNDAC, the European Commission, the Military Civil Defence Unit, the World Health Organization, and a variety of other actors (JEU, 2000).
Also at the international level, response for industrial accidents is provided via the United Nations Economic Commission for Europe's (UNECE) Industrial Accident Convention. UNECE applies to land-based, non-military, and non-radiological industrial accidents, and response is provided through bilateral or multilateral arrangements (UNECE, 2009). If no prior agreements exist, an affected country can request assistance from other parties through mutual assistance agreements. However, in these situations, it is the responsibility of the requesting country to cover all costs, unless otherwise agreed upon among the responding countries (UNECE, 2009). If an industrial accident occurs as a result of flooding, or other environmental effects, multiple disaster response frameworks must be triggered; therefore the Convention is not comprehensive enough to address cascading disasters in a holistic manner.

At the regional level, in our study areas, the Danube countries developed the DRPC in 1994, which is a legally binding instrument that ensures sustainable management of the Danube River (ICPDR, 1994). Through the ICPDR, the DRPC requested the ICPDR to coordinate the activities of the EU WFD and FD among the Danube member states. The WFD and FD are legally binding to members of the EU, but through the DRPC become legally binding to all Danube member states, regardless of EU member status. The WFD combines the monitoring and assessment of water quality in the basin, and the FD instructs national authorities to establish flood risk management plans by 2015 , linking the objectives of the WFD and the risk to these objectives from flooding or coastal erosion through the FD and integrating them into basin level activities via the ICPDR. However, because not all countries of the Danube are EU member states, not all measures and outcomes of the WFD and FD are implemented equally among the basin countries. Though the FD was expected to reduce flood risk, interviewees voiced disappointment regarding the limitations of integrating disaster risk more broadly, particularly in relation to water quality and accidental pollution [3]. Thus, the WFD and FD have substantial policy limitations, as neither of the two directives requires the integration of disaster risk of both floods and accidental pollution.

The EU's CPM is an instrument for disaster response that protects people, the environment, property, and cultural heritage in the event of natural or man-made disasters, occurring within or outside of the European Community (European Commission, 2016). Disasters are monitored internationally through the Emergency Response Coordination Centre (ERCC) in cooperation with the JEU and with participating states. The ERCC and JEU interface with a diverse system of response among the Danube basin countries due to the variety of disasters experienced. Some countries utilize a single CPM, while others rely on multiple parties among ministries of the interior, ministries of rural development, water directorates, and a variety of additional local protection committees $[4,5]$. Interviews indicated that not all re- 
sponders or parties are sufficiently trained, and many lack managerial or technical capacity to manage specific disasters appropriately [4]. There is also large compartmentalization of tasks at lower levels - both regional and local - where integration among the various types of disaster, as well as increased cooperation, is needed $[2,3]$. Other than the fact that these diverse actors are providing certain types of disaster assistance, there is nothing uniting them - there is no international or regional disaster response system. Limitations in funding, technical expertise, and capacity were confirmed in interviews with experts at various levels, who also noted how this leads to uneven implementation of EU directives within the basin that can create pockets of vulnerability to both flood risk and risks from industrial accidents [2-4]. Experts also expressed the need for formal agreements with specific language on integrated mapping of cascading disasters, as well as provisions addressing response to both natural and man-made disasters, particularly if additional grants could be given from the EU to support these activities [2-5]. Some interviewees reflected that the regional Danube Strategy depended on stronger countries helping the weaker ones, but limitations with funding and capacity are difficult to overcome [2].

In the 2015 annual report on implementation of the Danube Strategy produced by the Danube countries, all projects focused on implementation of the FD. The only mention of industrial accidents was to reflect the failure to include an updated Inventory of Potential Accidental Risk Spots along the Danube, which is also discussed in the 2015 Danube River Basin Management Plan (DRBMP) (EUSDR, 2015; ICPDR, 2015b). Given past issues with mine-tailing collapses and other pollution disasters associated with flooding, the 2015 DRBMP acknowledged the need to update the Inventory of Potential Accidental Risk Spots promptly (ICPDR, 2015b). Unfortunately, this recommendation from the 2015 DRBMP, and initially expressed in the first DRBMP of 2009 , has yet to be realized.

The DRPC is supplemented by a series of non-binding memoranda of understanding (MOU) referred to as the Danube Declarations, first agreed upon in 2004, revised in 2010, and updated in 2016. Under this umbrella, the Danube River basin countries engage currently in two separate systems: the Emergency Flood Alert System (associated with the EU) for flood monitoring and the Principal International Alert Centres (PIACs) of the Danube Accident Emergency Warning System (AEWS, not associated with EU institutions) to monitor pollution from man-made accidents. These two separate systems illustrate well the issues associated with separate response mechanisms and institutional arrangements. The Emergency Flood Alert System has been functioning since 2003 at the Joint Research Centre, a Directorate General of the European Commission, and works in collaboration with the national authorities of the member states. Note that a MOU has been signed with several, but not all, of the Danube countries. The Emergency Flood Alert
System provides national authorities the ability to develop response measures, including opening temporary flood retention areas, building temporary flood protection structures such as sandbag walls, and adopting civil protection measures such as closing down water supply systems (ICPDR, 2009b). The MOU does not include tributaries draining areas less than $4000 \mathrm{~km}^{2}$; therefore the Emergency Flood Alert System addresses flood risks neither in the Tisza nor in certain basin countries where significant flood concerns arise, such as Ukraine [1].

The PIACs of the Danube AEWS monitor accidental water pollution incidents in the Danube River basin. Unlike the Emergency Flood Alert System, which is linked to monitoring conducted by the European Commission and is transmitted to national authorities (without involving the ICPDR in the monitoring process), the Danube AEWS is managed by the ICPDR but does not involve the European Commission. While all contracting parties of the DRPC cooperate with the Danube AEWS, they also are expected to have national policies regarding response to accidental pollution in the Danube that connects to the PIACs. The PIACs are expected to operate on a $24 \mathrm{~h}$ basis within each country and are in charge of all international communications. When a message of a potentially serious accidental pollution is received, the PIAC is responsible for communicating the accident to the ICPDR; it decides whether it is necessary to notify downstream countries and to engage experts to assess the impacts of the pollution, and it determines which response activities need to be taken at the national level (ICPDR, 2014). Challenges to the monitoring capabilities of the Danube AEWS include territorial gaps (several areas along the Danube and Tisza are not monitored) [3-5], a limited number of bilateral agreements for response in case the accident exceeds national capacity (Table 2), and a non-comprehensive list of man-made accidents being monitored. The failure to monitor pollution events in a consistent and effective manner creates difficulties for downstream countries [4]. This is particularly problematic in the Tisza countries, where the lack of monitoring of both flood and accidental pollution events, combined with limited bilateral agreements, raises concern among several countries $[4,5]$.

Bilateral agreements are also in place to address transboundary flood measures among Danube countries and, to a smaller extent, to respond to man-made disasters. Bulgaria, Moldova, Romania, Serbia, and Ukraine are parties to the DRPC but have separately engaged in the BSEC Collaboration in Emergency Assistance and Emergency Response to Natural and Man-Made Disasters (Bruch et al., 2016). Furthermore, the Danube Delta countries (Moldova, Romania, and Ukraine) are working together with the UNECE Industrial Accidents Convention due to the large concentration of oil-related industries in the area in order to improve hazard management, increase transboundary cooperation, and strengthen operational response [1]. 


\section{Building holistic approaches for disaster response}

While "natural" disasters may be a commonly used term, no disaster can be regarded as entirely natural if people have the capacity to avoid, mitigate, or reduce the risk from it (Picard, 2016). Generally, the vulnerability to lives and livelihoods can be reduced with disaster preparedness and response, such as the proper placement, function, and use of early warning systems and mitigation activities. Additional shifts in what is considered a natural disaster have come from the acknowledgement of the anthropogenic influences on natural disasters. Besides climate change, there are also induced earthquakes occurring as a result of slipping faults from fluid injection in hydraulic fracturing (Legere, 2016), landslides from subsidence and increased land use activities including urbanization (Smith, 2013), and pandemics from deforestation and habitat conversion (Greger, 2007), to name a few.

Human, economic, and environmental losses can be worse in highly populated, urbanized areas; with increased urbanization and climate change, these areas are placed at increased risk to natural and man-made hazards (Bruch and Goldman, 2012; Huppert and Sparks, 2007).This is especially true for natech accidents and other cascading disasters, since simultaneous response efforts are required to attend to the industrial, chemical, or technological accidents as well as the triggered natural disaster. The overlap from numerous responders, the activation of numerous - and disparate - response frameworks, and the difficulties in integrating the separate response activities make fragmented frameworks of disaster response costly and ineffective. Therefore, expanded definitions that reflect multiple types of disaster, as well as improved comprehensive response frameworks, are needed in order to recognize that many disasters can arise from multiple, potentially co-located, hazards to take the necessary measures to reduce the risks of those hazards and to holistically address their impacts. Otherwise, piecemeal, uncoordinated responses may result in duplication of costs and activities and, more importantly, overlooked health and environmental consequences.

The process of developing a holistic approach to natural and man-made disasters (i.e., adopting a multi-hazard approach) can further be integrated into other areas of the disaster cycle, including planning, preparedness, response, and recovery. These approaches may be implemented at the global, regional, bilateral, or national levels. By adopting a multihazard framework for disaster response, the expertise and practices of responders can be increased to include improved modeling and assessment approaches, response methodologies and tools, and enhanced measures to prevent or mitigate the consequences from natech accidents (Krausmann et al., 2017).

The review of legal and policy frameworks and interviews reflected that while some preparedness activities take place regarding flood hazard, this is not the case for accidental pollution (at least in the Danube and Tisza context), and natech accidents are absent in the framework language [2-6] (European Commission, 2010; ICPDR, 2015a). Monitoring gaps are reported along the length of both the Danube and the Tisza for both flooding and accidental pollution, and these gaps should be corrected in future planning efforts. The Tisza sub-basin and smaller water bodies are beyond the scope of the WFD and, consequently, no holistic monitoring or response measures are in place; regional agreements at the basin or sub-basin level could aid in developing improved response frameworks [2, 3](McClain et al., 2016).

Improving the mapping of hazards to reflect not only flood hazard, but also risks from man-made disasters and natech events - and integrating these risks into a comprehensive map of vulnerability to disaster - would provide a foundation for more holistic policies and programming to manage disaster risks. It would also aid in improving measures for preparedness at the national and local levels. Interviews indicate that harmonized approaches to natural and man-made disasters offer additional opportunities to strengthen capacity among transboundary actors $[1,4]$.

In order to avoid fragmentation among response to natural and man-made disasters, and empower, guide, and facilitate the institutional arrangements and mandates necessary to improve these activities, the legal and policy frameworks need to provide the necessary mandates and procedures - this is accomplished by incorporating an integrated, multi-hazard approach to disaster response. Though this can be challenging, there is a growing literature concerning the development of the technical and policy tools necessary (Kappes et al., 2012; Holub and Fuchs, 2009) and how to address fairness considerations (Thaler and Hartmann, 2016). There are multiple examples of more holistic and comprehensive approaches being used in the EU countries (Grieving et al., 2012; Thaler et al., 2016). Such approaches emphasize stakeholder involvement and adaptive management and could form a blueprint for efforts in the Danube and the Tisza.

With regard to the Danube basin specifically, a more holistic approach that accounts for the specific challenges of the basin could be implemented in a variety of ways. The DRPC has not been updated or amended since it was originally drafted in 1994, but it unites all countries of the Danube basin and its tributaries under a formal legal agreement. Cooperation among Danube countries was generally reported as good [3]; therefore, continuing the use of the ICPDR and its expert groups as a mechanism to gain cooperation among the countries on a regional framework for improving monitoring and response could be considered [3-5]. Another possibility would be to expand the numerous bilateral agreements among the Danube and Tisza countries regarding flooding to also include man-made disasters and natech events. Working on agreements at a regional level improves communication, breaks down barriers (particularly in transboundary situations), and aids in the development of a common legal language among participating parties [1,2]. 
Updating conventions and other hard law (e.g., legal frameworks) can be difficult; countries are sometimes unwilling to adopt binding obligations, particularly in the face of uncertainty (e.g., climate change), or when they feel there might be a need to act quickly to changing circumstances. Soft law (e.g., policies and guidelines) is often argued as a more flexible tool. In this regard, updating the Danube Declaration and the corresponding Tisza MOU can provide particularly viable options. Through the declarations and MOU, the Danube or Tisza countries could decide whether to engage in a particular action through a separate strategy, or pilot project, or whether to incorporate the issue into the broader basin or sub-basin management plan (e.g., improvement of accidental pollution and flood monitoring, integrated accidental pollution and flood maps). Improved vertical and horizontal cooperation was a need identified by several interviewees, particularly in regard to the risks posed from manmade accidents and how to respond to these accidents $[4,5]$.

\section{Conclusions}

The historic distinction between natural and man-made disasters is outdated, counterproductive, and ultimately flawed. The recognition of this has resulted in the need to address disasters holistically, regardless of the contributing causes and aggravating factors. This trend is noted in the Sendai Framework, which adopts a multi-hazard risk approach and provides tools for responding to disasters that are both natural and man-made (UNISDR, 2015).

The Danube and Tisza countries have already been affected multiple times by transboundary natural and manmade disasters and natech accidents. Nevertheless, though approaches for integrating holistic frameworks for disaster response are recognized at multiple levels, implementation within the Danube basin and Tisza sub-basin remains distinct and fragmented. While the current policy frameworks do not address monitoring and response comprehensively across types of disasters, the basin countries have several options for more integrated response. A key opportunity is the development or amendment of agreements governing response to natural and man-made disasters. This could be negotiated through updates to the Danube Convention or through bilateral treaties between the basin countries. Improving planning and preparedness through more integrated monitoring and mapping of natural and man-made disasters, such as combining the flood risk areas with the Inventory of Potential Accidental Risk Spots, could be elaborated upon in declarations and MOU at the basin and sub-basin levels. Such negotiations and the resulting increased coordination will become even more critical as climate change is likely to increase the frequency and severity of extreme events in the foreseeable future.
Data availability. The data are not publicly available, but interested parties can contact the corresponding author.

Competing interests. The authors declare that they have no conflict of interest.

Acknowledgements. This material is based upon work supported by the United States' National Science Foundation under grant no. 0903510. Any opinions expressed here are those of the authors and do not necessarily reflect the views of the National Science Foundation.

We thank the Southern Illinois University IGERT Program in Watershed Science and Policy and associated colleagues for their support. The authors are also grateful for the suggestions and comments of Cindy Buys. We additionally thank the International Commission for the Protection of the Danube River (ICPDR) for assisting in obtaining data and for hosting Shanna while she conducted her research.

Edited by: Thomas Glade

Reviewed by: Sven Fuchs and one anonymous referee

\section{References}

Aitsi-Selmi, A. and Murray, V.: The Chernobyl Disaster and Beyond: Implications of the Sendai Framework for Disaster Risk Reduction 2015-2030, PLOS Medicine, 13, 1-4, 2016.

ASEAN - Association of South East Asian Nations: ASEAN Agreement on Disaster Management and Emergency Response: Work Programme 2010-2015, ASEAN, Jakarta, http://www.asean.org/wp-content/ uploads/images/resources/ASEANPublication/2013(12.Dec)

-AADMERWorkProgramme(4thReprint).pdf (last access: 7 July 2016), 2010.

Barredo, J. I.: Normalised flood losses in Europe: 19702006, Nat. Hazards Earth Syst. Sci., 9, 97-104, https://doi.org/10.5194/nhess-9-97-2009, 2009.

Bruch, C. and Goldman, L.: Keeping up with Megatrends: the implications of climate change and urbanization for environmental emergency preparedness and response, Office for the Coordination of Humanitarian Affairs, Joint UNEP/OCHA Environment Unit, Emergency Services Branch, Geneva, Switzerland, 2012.

Bruch, C., Nijenhuis, R., and McClain, S. N.: International Frameworks Governing Environmental Emergency Preparedness and Response: An Assessment of Approaches, in: The Role of International Environmental Law in Reducing Disaster Risk, edited by: Peel, J. and Fisher, D., Brill Nijhoff, Leiden, 2016.

BSEC - Black Sea Economic Cooperation: Agreement among the Governments of the Participating States of the Black Sea Economic Cooperation (BSEC) on Collaboration in Emergency Assistance and Emergency Response to Natural and Man-Made Disasters, http://www.bsec-organization.org/ documents/LegalDocuments/agreementmous/agr4/Documents/ Emergencyagreement071116.pdf (last access: 7 July 2016), 1998. 
Cutter, S. L. and Emrich, C. T.: Are natural hazards and disaster losses in the U.S. increasing?, Eos Trans. Am. Geophys. Un., 86, 381-389, 2005.

European Commission: Communication from the Commission to the European Parliament, the Council, the European Economic and Social Committee, and the Committee of the Regions: European Strategy for the Danube Region, COM, 715 Final, Brussels, Belgium, 2010.

European Commission: EU Civil Protection Mechanism, http:// ec.europa.eu/echo/what/civil-protection/mechanism_en, last access: 2 July 2016.

EUROSATA: Countries, 2014 - Administrative Units - Dataset, https://webgate.ec.europa.eu/fpfis/wikis/x/vQXOB (last access: 5 September 2017), 2014.

EUSDR - European Union Strategy for the Danube Region Danube Region Strategy Priority Area 5: To Manage Environmental Risks, Coordinated by Hungary and Romania, Budapest, Hungary, June 2015.

Fisher, D.: The Law of International Disaster Response: Overview and Ramifications, Int. Law Stud., 83, 293-320, 2008.

Greger, M.: The Human/Animal Interface: Emergence and Resurgence of Zoonotic Infectious Diseases, Crit. Rev. Microbiol., 33, 243-299, 2007.

Greiving, S., Pratzler-Wanczura, S., Sapountzaki, K., Ferri, F., Grifoni, P., Firus, K., and Xanthopoulos, G.: Linking the actors and policies throughout the disaster management cycle by "Agreement on Objectives" - a new output-oriented management approach, Nat. Hazards Earth Syst. Sci., 12, 1085-1107, https://doi.org/10.5194/nhess-12-1085-2012, 2012.

Holub, M. and Fuchs, S.: Mitigating mountain hazards in Austria - legislation, risk transfer, and awareness building, Nat. Hazards Earth Syst. Sci., 9, 523-537, https://doi.org/10.5194/nhess9-523-2009, 2009.

Huppert, H. E. and Sparks, R. S. J.: Extreme Natural Hazards: Population Growth, Globalization and Environmental Change, Philos. T. Roy. Soc., 364, 1875-1888, 2007.

ICPDR - International Commission for the Protection of the Danube River: Danube River Protection Convention, ICPDR, Vienna, https://www.icpdr.org/main/sites/default/files/ DRPCEnglishver.pdf (last access: 3 June 2016), 1994.

ICPDR - International Commission for the Protection of the Danube River: Analysis of the Tisza River Basin 2007, ICPDR, Vienna, http://www.icpdr.org/main/sites/default/files/Tisza_RB_ Analysis_2007.pdf (last access: 31 May 2016), 2008.

ICPDR - International Commission for the Protection of the Danube River: The Danube River Basin District Management Plan: Part A - Basin-wide Overview, ICPDR, Vienna, http: //www.icpdr.org/main/sites/default/files/DRBM_Plan_2009.pdf (last access: 27 June 2016), 2009a.

ICPDR - International Commission for the Protection of the Danube River: Assessment of Flood Monitoring and Forecasting in the Danube River Basin, ICPDR, Vienna, http://www.icpdr.org/main/sites/default/files/OM-12-3.

6ASSESSMENTofFloodMonitoringFINAL.pdf (last access: 1 June 2016), 2009b.

ICPDR - International Commission for the Protection of the Danube River: New International System for Early Flood Warning in Danube River Basin Launche, https://www.icpdr.org/main/sites/default/files/nodes/documents/ 080310_efas_pr_final_icpdr.pdf (last access: 27 June 2016), March 2010.

ICPDR - International Commission for the Protection of the Danube River: Memorandum of Understanding: Towards the Implementation of the Integrated Tisza River Basin Management Plan Supporting the Sustainable Development of the Region, ICPDR, Vienna, 2011.

ICPDR - International Commission for the Protection of the Danube River: Danube River Basin Boundaries, Vienna, Austria, 2013.

ICPDR - International Commission for the Protection of the Danube River: International Operations Manual for PIACs of the Danube AEWS, ICPDR, Vienna, http://www.icpdr.org/main/sites/default/files/nodes/documents/ aews_manual_2014_final.pdf (last access: 3 April 2016), 2014.

ICPDR - International Commission for the Protection of the Danube River: The Danube River Basin District Management Plan - Update 2015, ICPDR, Vienna, https://www.icpdr.org/main/sites/default/files/nodes/documents/ drbmp-update2015.pdf (last access: 31 May 2016), 2015a.

ICPDR - International Commission for the Protection of the Danube River: Flood Risk Management Plan for the Danube River Basin District, ICPDR, Vienna, https://www.icpdr.org/ main/sites/default/files/nodes/documents/1stdfrmp-final_1.pdf (last access: 31 May 2016), 2015b.

IFRC - International Federation of Red Cross and Red Crescent Societies: Law and Legal Issues in International Disaster Response: A Desk Study, IFRC, Geneva, 2007.

Janssen, M., Lee, J., Bharosa, N., and Cresswell, A.: Advances in multi-agency disaster management: Key elements in disaster research, Inform. Syst. Front., 12, 1-7, 2010.

JEU - Joint United Nations Environment Programme (UNEP)/Office for the Coordination of Humanitarian Affairs (OCHA) Environment Unit: Cyanide Spill at Baia Mare Romania: Spill of Liquid and Suspended Waste at the Aurul S.A. Retreatement Plant, OCHA, Geneva, 2000.

Kappes, M., Keiler, M., von Elverfeldt, K., and Glade, T.: Challenges of analyzing multihazard risk: A review, Nat. Hazards, 64, 1925-1958, 2012.

Krausmann, E. and Baranzini, D.: Natech Risk Reduction in the European Union, J. Risk Res., 15, 1027-1047, 2012.

Krausmann, E., Cruz, A. M., and Salzano, E.: Natech Risk Assessment and Management: Reducing the Risks of Natural-hazard Impact on Hazardous Installations, Elsevier, Amsterdam, 2017.

Legere, L.: State Seismic Network Helps Tell Fracking Quakes from Natural Ones, Pittsburgh PostGazette, 26 June 2016, http://powersource.post-gazette. com/powersource/policy-powersource/2016/06/26/

State-seismic-network-helps-tell-fracking-quakes-from-natural-ones/ stories/201606210014, last access: 30 June 2016.

Lehner, B., Verdin, K., and Jarvis, A.: New global hydrography derived from spaceborne elevation data, Eos Trans. AGU, 89, $93-$ 94, 2008.

McClain, S. N., Bruch, C., and Secchi, S.: Adaptation in the Tisza: Innovation and Tribulation at the Sub-basin Level, Water Int., 41, 813-834, 2016.

Nagy, I., Ligetvári, F., and Schweitzer, F.: Tisza River Valley: Future Prospects, Hungar. Geogr. Bull., 59, 361-370, 2010. 
NERC - Natural Environmental Research Council: UNDAC Landslide Advisory Visit to Serbia June 2014, Open Report IR/14/043, edited by: Hobbs, P., Keyworth: British Geological Survey, Keyworth, Nottingham, UK, 2014.

OECD - Organization for Economic Cooperation and Development: Addendum No. 2 to the OECD Guiding Principles for Chemical Accident Prevention, Preparedness, and Response (2nd Edn.) to Address Natural Hazards Triggering Technological Accidents (Natechs), http: //www.oecd.org/officialdocuments/publicdisplaydocumentpdf/ ?cote $=$ env $/ \mathrm{jm} / \mathrm{mono}(2015) 1 \&$ doclanguage $=$ en (last access: 28 June 2016), 2015.

Peel, J. and Fisher, D.: International Law at the Intersection of Environmental Protection and Disaster Risk Reduction, in: The Role of International Environmental Law in Reducing Disaster Risk, edited by: Peel, J. and Fisher, D., Brill Nijhoff, Leiden, 2016.

Pescaroli, G. and Alexander, D.: A definition of cascading disasters and cascading effects: Going beyond the "toppling dominos" metaphor, Planet Risk, 2, 58-67, 2015.

Picard, M.: Water Treaty Regimes as a Vehicle for Cooperation to Reduce Water-Related Disaster Risk: The Case of Southern Africa and the Zambesi Basin, in: The Role of International Environmental Law in Reducing Disaster Risk, edited by: Peel, J. and Fisher, D., Brill Nijhoff, Leiden, 2016.

Rozario, K.: The Culture of Calamity: Disaster \& the Making of Modern America, University of Chicago Press, Chicago, 2007.

Schneider, E.: Floodplain Restoration of Large European Rivers, with Examples from the Rhine and the Danube, in: Restoration of Lakes, Streams, Floodplains, and Bogs in Europe: Principles and Case Studies, Springer Science, USA, 185-223 2010.

Shelton, D. (Ed.): Commitment and Compliance: The Role of Nonbinding Norms in the International Legal System, Oxford University Press, Oxford, 2000.

Smith, K.: Environmental Hazards: Assessing Risk and Reducing Hazard, Routledge, New York, 2013.
Sun, L. G.: Climate Change and the Narrative of Disaster, in: The Role of International Environmental Law in Reducing Disaster Risk, edited by: Peel, J. and Fisher, D., Brill Nijhoff, Leiden, 2016.

Swiss Re: Natural Catastrophes and Man-Made Disasters in 2015: Asia Suffers Substantial Losses, Sigma Report No. 1/2016, Swiss Re, Zurich, http://media.swissre.com/documents/sigma1_ 2016_en.pdf, last access: 1 June 2016.

Thaler, T. and Hartmann, T.: Justice and flood risk management: reflecting on different approaches to distribute and allocate flood risk management in Europe, Nat. Hazards, 83, 129-147, 2016.

Thaler, T. A., Priest, S. J., and Fuchs, S.: Evolving inter-regional cooperation in flood risk management: distances and types of partnership approaches in Austria, Reg. Environ. Change, 16, 841853, 2016.

UNECE - United Nations Economic Commission for Europe: Guidance on Water and Adaptation to Climate Change, United Nations, Geneva, 2009.

UNECE - United Nations Economic Commission for Europe: Second Assessment of Transboundary Rivers, Lakes and Groundwaters, UNECE, New York, Geneva, 2011.

UNEP - United Nations Environment Programme: Enhanced Coordination Across the United Nations System, Including the Environment Management Group, Twenty-Sixth Session, UNEP/GC.26/15, Nairobi, Kenya, 2011.

UNISDR - United Nations Institute for Disaster Reduction: Sendai Framework for Disaster Risk Reduction: 2015-2030, UNISDR, Geneva, 2015.

Venturini, G.: International Disaster Response Law in Relation to Other Branches of International Law, in: International Disaster Response Law, edited by: de Guttry, A., Gestri, M., and Venturini, G., T. M. C. Asser Press, The Hague, the Netherlands, 2012. 